hours of study is 8 for chemistry, ro for physiology and 6 for nutrition, that is, 200,250 and 150 hours per session, respectively. In physiology fundamental study of the whole subject will be begun in the 2 nd year and continued through the last 2 years of the course, with special attention to chemical physiology in the final year. In nutrition it is proposed that the 2nd-year student shall begin with a thorough training in the preparation of food and the composition of foodstuffs. Then in the last year of the course, when the greater part of the time is given to nutrition, the subjects covered will be plants and animals that contribute to the production of food; functions of nutrients and the effects of deficiency; chemical, biological and microbiological methods of estimating nutrients; formulation of dietaries; methods of dietary survey and assessment of nutritional status; nutrition and metabolism of micro-organisms; food hygiene, food preservation and food spoilage; economic and sociological aspects of food production and consumption. A short course in statistics will be included.

This account has tried to indicate the wide field to be covered if students are to acquire the label B.Sc. (Nutrition) with a state of knowledge adequate for their immediate absorption into laboratories doing food research or into nutrition research teams taking part in laboratory or field work. It is important for the student of nutrition to realize the psychological and economic as well as the physiological factors involved in the problem of adequate nutrition and that the subject in fact offers world-wide scope for study and advancement of knowledge. Nutrition must be taken to include not only the nutrition of man, but also the closely related nutrition of plants, animals and micro-organisms. Only by giving as wide a training as possible in the available time can we justify our own faith in this new degree and send out graduates in nutrition who will be useful members of society in a world that has an ever growing problem of feeding its hungry populations.

\title{
Education in Animal Nutrition
}

\section{By J. Hammond, School of Agriculture, University of Cambridge}

In order to meet the ever-changing needs of teaching in animal nutrition it must be based on active and well organized research dealing with current problems in the subject. Thus before the war we were well supplied with high-protein feedingstuffs, such as oilcakes, while now we have to supply the majority of our feedingstuffs from our own farms to produce a much greater volume of milk than before the war. It is necessary, therefore, to consider briefly the position of organized research on the subject.

\section{Research Institutes}

About rgr I three Research Institutes in Animal Nutrition were set up in conjunction with the Departments of Agriculture at the Universities of Aberdeen, 
Cambridge and Leeds, where teams of workers set out to investigate the problems of the day. In general, Aberdeen undertook work on mineral metabolism, vitamins and trace elements, while Cambridge and Leeds specialized in energy nutrition and protein requirements; later at Cambridge the effects of the planes of nutrition on the distribution of nutrients to the different tissues were studied also. After the I I I 4-I 8 war the Institute at Leeds was liquidated and its workers were transferred to Cambridge and elsewhere. After the 1939-45 war the Institute at Cambridge also was liquidated and its workers were transferred to the teaching staff or to Aberdeen. Meanwhile, however, extensive nutritional research had developed in connexion with Research Institutes formed for dairying at Reading (for England and Wales) and in Ayr, at the Hannah (for Scotland). Here work developed on the nutrition of the dairy cow and calf, and also on pigs at the former, which in those days depended on the by-products of the dairy industry. When these by-products ceased to become available for pigs the work at Reading naturally turned to vitamins and mineral requirements as substitutes. Some nutritional research, mostly applying to deficiencies and disease, was carried out at the Veterinary Research Institutes at Weybridge and at Moredun, while lately at the Grassland Research Station at Hurley the now most important subject of grass as a food for livestock came under investigation. Research on nutrition is in progress also at other University Departments of Agriculture, such as those at the Universities of Durham, London and Nottingham, but it is carried out for the most part by workers who are already overloaded with teaching duties, so that the volume of work is not great and the direction is somewhat erratic. Most of this research is now supported by grants from the Agricultural Research Council.

\section{Teaching at University levels}

Graduate. In those Universities, at or near which Research Institutes are located, special courses are given on animal nutrition, often running 3 days a week throughout three terms. They consist of both lectures and practical work and include the methods of feeding-stuff analysis. All candidates for a degree have to pass in this subject. These lectures were frequently given by members of the Research Institute and thus the teaching was dynamic and related to problems of current needs and did not tend to become static and repeated in much the same form year after year, as often happens when the teacher is doing no research himself. In some of the other Universities the subject is split between agricultural chemistry, in which the methods of food analysis, the composition of feeding-stuffs and the nutrient requirements for the various types of production are taught, and animal husbandry, in which the student is instructed in the methods of compounding a suitable ration from feeding-stuffs available on the farm and on what is necessary to buy to supplement them for the purpose in view.

In general, the form the teaching takes is first historical, showing how by respiration chambers, calorimeters, balance experiments and so on, the food requirements for maintenance of the different species at different body-weights have been determined and what in addition is required for each pound of live-weight gain or 
gallon of milk produced. For commercial purposes full utilization of the food is required, and much attention is therefore paid to factors affecting the conversion rates in different species; for example, though the young pig converts proteins more efficiently than carbohydrates, the reverse is true of the older bacon pig. The ratio of protein to energy for animals in different phases of life (growth, lactation, fattening) demands attention also, because protein feeds are more expensive than carbohydrates. Tables for the composition of different feeding-stuffs and their digestibility coefficients for different species have been drawn up by the Research Institutes (Woodman, 1952) and are used for compounding rations.

Attention has to be given to the bulk and the fibre content of any ration, especially for pigs, poultry and all young animals whose intake limit is set by stomach capacity, as well as to energy and protein intake.

Stress is laid also on the sharp differences between ruminants (cattle and sheep), which digest cellulose and manufacture their own vitamin $B_{12}$ but are liable to cobalt deficiency, and the simple-stomach animals (pigs and poultry) which do not, and so require animal proteins, vitamin $B_{12}$ or antibiotics. The substitution of vegetable protein with the last two for animal protein is one of the important problems now being worked out.

Lately, too, the effect of the plane of nutrition on the partition of nutrients to the different parts of the body and to the different tissues is receiving some consideration.

In addition, the best methods of preserving for winter feeding foods produced in summer are taught, for the losses, not only of protein and energy but also of vitamins, may be considerable in badly made silage or hay.

Postgraduate. In many of the Universities, more especially in those where there is a nearby Research Institute, graduates are working for an M.Sc. or Ph.D. degree on some nutritional problem. These men will later take up a post at a Research Institute or become lecturers in animal nutrition. In addition, at Cambridge honours graduates in science take an Agricultural Diploma in which animal nutrition is a subject. These men go on to do research or more frequently join the advisory services (see below) or become Colonial Agricultural Officers.

Teaching at Farm Institutes. Farm Institutes are set up by the Education Committees of different counties under the Ministry of Education for teaching young people who will go into the farming industry; they are staffed by graduates of Agricultural Colleges. The teaching in nutrition is given under the heading of 'Animal Husbandry' and is mainly about the compounding of suitable rations on the basis of the feeding-stuffs tables issued by the Research Institutes for maintenance of different types of farm animals and for different types of production (growth, milk, fattening) and what feeding-stuffs it is necessary to buy to supplement homegrown supplies. The pupils are made acquainted also with the signs that develop from a deficiency in minerals, trace elements or vitamins.

\section{National Agricultural Advisory Service}

The Ministry of Agriculture has an advisory service providing adult education 
for the farmer. The service is staffed by those who have had postgraduate or graduate training. While all members of the staff have had some training in animal nutrition, at each Provincial Headquarters (England and Wales) or University Centre (Scotland) there is a specialist Nutrition Officer who gives on special problems of nutrition advice that is of too advanced a nature for the local unspecialized advisory officer. Such specialized officers are in touch with the Research Institutes and receive information on current research problems both in this country and abroad from the publications of the Commonwealth Bureau of Animal Nutrition at Aberdeen. It is the duty of the Bureau to abstract all research literature on animal nutrition and to publish the abstracts and review articles periodically.

Not only does the National Agricultural Advisory Service deal with queries from farmers, but it also spreads the newer knowledge in animal nutrition to the farmers by arranging lectures at suitable times and places.

Under the direction of the Agricultural Improvement Council of the Ministry of Agriculture an attempt is made to extend the findings of research into agricultural practice at various Husbandry Farms throughout the country. For example, at a farm at Trawscoed near Aberystwyth young heifers are being reared on high and low planes of nutrition, to determine what will be the effects on the partition of nutrients between growth and milk production at different stages of life. Experiments with antibiotics in pig feeding are being made on some of these farms also. Visits of farmers to see such practical experiments in progress stimulate them to study the results of nutritional research and show them how best the results can be put into practice.

In addition to these organizations for teaching and research, more or less Government sponsored, much work on education in animal nutrition is carried out by large feeding-stuffs manufacturers, who have their own nutrition experts. These are often given refresher courses at Agricultural Colleges. Such firms also have their own experimental farms and pioneer new developments among the farmers. For example, one of them has for the last few years run a litter testing station for pigs, where the strains that have the power of converting feeding-stuffs into meat most efficiently are picked out and used as breeding stock.

REFERENCE

Woodman, H. E. (1952). Bull. Minist. Agric., Lond., no. 48.

\section{Nutritional Education in the Army}

\section{By Freda S. Leben, Army Medical Directorate, The War Office,} London, S.W.I

Efficient nutrition in the Army is of great importance for three reasons. It helps maintain good health amongst the troops; it helps keep up the standard of physical efficiency the army requires; it helps maintain morale. 